\title{
Penentuan Harga Jual Biji Jarak Kering Dengan Metode Activity Based Cost System Untuk Mendukung Pertanian Berkelanjutan: Studi Kasus Nusa Penida, Bali
}

\author{
Radha Kurniawan $^{1}$, Rukmi Sari Hartati ${ }^{2}$, I N Satya Kumara ${ }^{3}$ \\ [Submission: 27-10-2018, Accepted: 22-06-2019]
}

\begin{abstract}
The aim of this research was to determine the price of jatropha seed at farmer level in Nusa Penida island, Bali, where the location was highly potential for Jatropha seed development as the main raw material of biodiesel production. The biodiesel price wass calculated using Activity-Based Cost System method. This method calculated biodiesel's prices more accurate because it took a detailed activities costing in the biodiesel processing. The activities consisted of the production process activities at the unit and batch levels, where the costs were grouped by activity type according to Activity-Based Cost System, then grouped again into activity cost pool. It was found that the biodiesel price was Rp. 4,076.25 per liter which was higher than the current price of Rp. 3,893.9 per liter. The calculated biodiesel prices was then calibrated against with the price of industrial diesel oil in Nusa Penida island further calculation was carried out to determine the price of dried Jathropha seeds.
\end{abstract}

Intisari- - Penelitian ini bertujuan mendapatkan harga jual biji jarak kering yang layak di tingkat petani di kawasan Nusa Penida, Bali, dimana lokasi tersebut sangat berpotensi akan perkembangan pohon jarak pagar sebagai bahan baku utama pembuatan biodiesel. Harga biodiesel tersebut dihitung menggunakan metode Activity-Based Cost System. Metode ini menghitung harga biodiesel lebih akurat karena memperhitungkan aktivitas-aktivitas yang lebih detail pada proses pengolahan biodiesel. Aktivitas yang dihitung adalah aktivitas-aktivitas proses produksi di tingkat unit dan batch, dimana biaya-biaya yang ada dikelompokkan berdasarkan jenis aktivitas menurut Activity-Based Cost System, kemudian dikelompokkan lagi ke dalam activity cost pool. Dalam penelitian ini, metode Activity-Based Cost System menghasilkan harga biodiesel Rp. 4.076,25 per liter dimana lebih tinggi dari metode tradisional sebesar Rp. 3.893,9 per liter. Harga biodiesel tersebut kemudian disetarakan dengan harga solar untuk industri di kawasan Nusa Penida dan dilakukan perhitungan untuk mendapatkan harga biji jarak kering.

Kata Kunci- Activity-Based Cost System, harga biji jarak pagar, biodiesel, Nusa Penida, Jatropha.

\footnotetext{
${ }^{1}$ Mahasiswa, Program Studi Magister Teknik Elektro, Fakultas Teknik, Universitas Udayana, Jl. Kampus Bukit Jimbaran, 80361 INDONESIA,(tlp:081805589809;email: radha.kurniawan@gmail.com)

${ }^{2,}{ }^{3}$ Dosen, Program Studi Magister Teknik Elektro, Fakultas Teknik, Universitas Udayana, Jl. Kampus Bukit Jimbaran, 80361 INDONESIA (telp: 0361-703315; fax: 0361-4321; e-mail: rshartati@gmail.com,satya.kumara@unud.ac.id )
}

Radha Kurniawan : Penentuan Harga Jual Biji...

\section{PENDAHULUAN}

Energi merupakan salah satu faktor penting dalam pembangunan suatu negara. Seiring dengan perkembangan suatu negara, pemanfaatan energi pun semakin besar. Sumber energi yang digunakan secara umum adalah sumber energi yang berasal dari fosil seperti batubara dan minyak bumi. Indonesia menggunakan minyak bumi sebagai salah satu sumber energinya. Disamping itu pula kebijakan pembangkitan energi listrik di pulau-pulau kecil didominasi oleh Pembangkit Listrik Tenaga Diesel (PLTD) yang bahan bakar utamanya menggunakan minyak diesel. Produksi bahan bakar minyak Indonesia pada tahun 2009 mencapai 254.875.512 barrels (KESDM, 2010). Produksi ini diperuntukkan bagi transportasi, rumah tangga, serta industri. Dari total produksi ini, 43,47\% atau mencapai 110.814 .865 barrels berupa solar atau Automotive Diesel Oil (ADO) yang digunakan pada pembangkitan listrik serta transportasi umum.

Sumber energi berbahan dasar minyak bumi bersifat tidak terbarukan, sehingga keberadaannya semakin lama semakin berkurang. Sesuai hukum pemasaran, produk dengan stok terbatas tetapi permintaan tinggi akan membuat harga produk tersebut tinggi. Harga minyak dunia pun cenderung mengalami peningkatan. Pada tahun 2008 harga minyak dunia sempat melampaui US \$140/barel mendorong pemerintah Indonesia menaikkan lagi harga BBM. Dampak kenaikan harga BBM sangat nyata bagi masyarakat di daerah terpencil. Di Nusa Penida, salah satu pulau kecil di Bali, harga solar untuk Pembangkit Listrik Tenaga Diesel (PLTD) mencapai Rp 6.300/liter pada saat harga di pasar Rp 4.300/liter. Pada saat diberlakukan harga solar Rp 5.500/liter, harga di Nusa Penida meningkat menjadi Rp 10.000/liter (Ardana dkk, 2008).

Biodiesel adalah salah satu energi alternatif yang juga merupakan sumber energi terbarukan.Dewasa ini biodiesel berkembang dengan cepat.Sebagai energi alternatif dan terbarukan, biodiesel dapat dihasilkan dari beberapa jenis tanaman.Biodiesel dapat dihasilkan dari pengolahan biji jarak, alga, maupun kelapa. Dari sekian bahan dasarnya, biji jarak merupakan bahan yang paling banyak digunakan. Brasil adalah salah satu negara penghasil biodiesel dengan bahan baku biji jarak terbesar di dunia. Untuk wilayah Asia, India merupakan penghasil utama biodiesel dengan biji jarak.

Di Indonesia, biodiesel mengggunakan biji jarak telah dikembangkan di beberapa daerah. Melihat karakteristik tanaman jarak yang hidup di lahan kering serta panas, pengembangan tanaman jarak di Indonesia difokuskan di daerah Bali serta Nusa Tenggara. Di Bali sendiri p-ISSN:1693 - 2951; e-ISSN: 2503-2372 
pengembangan dilakukan di Pulau Nusa Penida. Nusa Penida adalah sebuah pulau di bagian tenggara pulau Bali. Sumber daya alam disini berpotensi menggunakan sistem ketenagalistrikan hybrid dimana terdapat beberapa pembangkit listrik seperti PLTS (pembangkit Listrik Tenaga Surya), PLTB (pembangkit Listrik Tenaga Bayu), serta PLTD menggunakan diesel sebagai penopang suplai kelistrikan dari pulau Bali.

Kecamatan Nusa Penida meliputi 3 pulau, yaitu Nusa Penida, Nusa Ceningan dan Nusa Lembongan. Nusa Penida termasuk tipe iklim tropis yang dicirikan dengan suhu dan kelembaban relatif cukup tinggi dan hujan bermusim. Mengacu kepada kriteria klasifikasi kesesuaian lahan dan iklim untuk tanaman jarak pagar dan karakteristik iklim Nusa Penida, maka wilayah Nusa Penida termasuk ke dalam kriteria sesuai untuk pengembangan tanaman jarak pagar. Unsur iklim yang menjadi pembatas adalah ketersediaan air terutama pada bulan-bulan Agustus, September, dan Oktober yang merupakan puncak musim kemarau.

Berdasarkan hasil simulasi kelayakan finansial usaha tani jarak pagar di Nusa Penida oleh Ardana dkk (2008), titik impas tercapai pada tingkat harga biji kering jarak pagar Rp 2000/kg.Untuk mendapatkan keuntungan bagi para petani jarak, harga jual biji kering jarak pagar haruslah lebih besar dari Rp. 2.000/kg. Hasil pengolahan biji jarak ini diperuntukkan sebagai biodiesel untuk menjalankan PLTD yang selama ini masih menggunakan solar hasil pengolahan minyak bumi.PLN sendiri hanya mampu membeli seharga Rp. 500/kg biji kering jarak pagar dari petani. Hal ini membuat minat petani mengembangkan tanaman jarak berkurang. Sedangkan harga solar saat ini pun mengikuti harga minyak dunia yang terus berubah cenderung meningkat. Untuk itu, perlu dilakukan analisa penentuan harga biji kering jarak pagar menggunakan Activity-Based Cost System, dengan penyetaraan harga biodiesel jarak pagar dengan harga solar yang ada sehingga diperoleh harga jual wajar biji kering jarak pagar yang menguntungkan pihak petani maupun PLN selaku pelaku usaha ketenagalistrikan.

Activity-Based Cost System merupakan salah satu metode analisis biaya yang dikeluarkan dalam suatu proses produksi. Sistem ini menghitung biaya yang dikeluarkan oleh aktivitasaktivitas dalam proses produksi kemudian membebankannya pada biaya produksi.

Permasalahan yang difokuskan dalam penelitian ini adalah menganalisa harga jual biji kering jarak pagar dengan ActivityBased Cost System dan pendekatan kesetaraan harga biodiesel jarak pagar dengan harga minyak solar. Penelitian ini bertujuan untuk memberikan alternatif solusi penentuan harga jual biji kering jarak pagar yang wajar berdasarkan ActivityBased Cost System sehingga mampu meningkatkan kesejahteraan petani jarak pagar.

\section{BAHAN DAN METODE PENELITIAN}

Pada penelitian ini masalah yang akan dibahas dibatasi pada:

- Daerah studi adalah Pulau Nusa Penida, Kabupaten Klungkung, Provinsi Bali.

- Data harga harga minyak solar yang digunakan adalah harga solar untuk industri pembangkitan tenaga listrik tenaga diesel secara rata-rata selama bulan Januari 2015 sampai dengan April 2016 yakni sebesar Rp. 6.488 per liter.

- Dalam pengolahan data menggunakan Activity-Based Cost System, data yang digunakan adalah biaya-biaya yang ditimbulkan dalam aktivitas proses produksi biodiesel selama 1 (satu) tahun. Biaya yang difokuskan adalah biaya overheadpabrik dengan faktor pendorong aktivitas yang telah ditentukan perusahaan.

Dalam penelitian ini pendekatan yang dipakai adalah metode kuantitatif. Rancangan penelitian ini yaitu pertama, tahap identifikasi aktivitas pada proses pengolahan biji jarak menjadi minyak jarak. Tahapan ini dibagi menjadi 2 yaitu tahap pengolahan biji kering jarak pagar menjadi minyak jarak serta tahap pengolahan minyak jarak menjadi biodiesel. Kedua, menentukan jumlah aktivitas pada tiap tahapan di atas, bahan penunjang serta biaya-biayanya. Ketiga, menentukan kos aktivitas biodiesel dengan metode Activity-Based Object Costing. Pada proses ini, dilakukan dalam 4 tahapan yaitu :

- Pembebanan biaya aktivitas yang satu ke aktivitas yang lain

- Perhitungan activity driver rate untuk result-producing activity

- Pembebanan biaya result producing activity ke cost object

- Perhitungan kos produk/jasa

Dan yang keempat menentukan harga jual biji kering jarak pagar dengan menyetarakan harga biodiesel dari biji kering jarak pagar dengan harga minyak solar untuk industri pembangkitan tenaga listrik. Penentuan ini berdasarkan biaya aktivitas tiap proses pengolahan serta harga jual biodiesel dengan harga minyak solar.

Lokasi penelitian dilakukan di wilayah Kecamatan Nusa Penida, Kabupaten Klungkung, Bali. Waktu penelitian dilakukan mulai April 2012 sampai Oktober 2012. Pembahasan permasalahan dalam penelitian ini akan dibatasi hanya pada Metode penentuan kos produk menggunakan Activity-Based Costing System dan proses pengolahan biji jarak yang digunakan adalah proses untuk skala kecil dengan kapasitas produksi 150 liter biodiesel per hari. Harga minyak solar yang digunakan sebagai penyetara adalah harga beli minyak solar untuk industri pembangkitan listrik tenaga diesel. Data-data yang diperoleh dalam penelitian ini dikelompokkan menjadi dua jenis yaitu:

- Data Primer. Data Primer merupakan data yang diperoleh berdasarkan hasil penelitian di lapangan, seperti harga beli bahan penunjang proses pengolahan minyak jarak, harga jual biji jarak kering di pasaran, serta harga solar untuk industri yang dirata-ratakan dalam kurun waktu setahun terakhir.

- Data Sekunder. Data Sekunder merupakan data yang diperoleh melalui literatur maupun dokumen instansi yang berhubungan dengan kelistrikan di Nusa Penida, penyebaran petani jarak, serta perhitungan kelayakan usaha dari penelitian terdahulu.

Dalam penelitian ini, pengumpulan data yang diperoleh didasarkan pada metode-metode berikut ini:

- Metode Observasi, yaitu pengumpulan data dengan mengadakan pengamatan secara langsung di wilayah Kecamatan Nusa Penida menggunakan panca indera peneliti langsung sebagai instrumennya. 
Majalah Ilmiah Teknologi Elektro, Vol. 18, No. 2, Mei - Agustus 2019

DOI: https://doi.org/10.24843/MITE.2019.v18i02.P05

- Studi Literatur, yaitu mengumpulkan data dari bukubuku referensi, maupun modul-modul yang relevan dengan objek permasalahan.

- Wawancara, data di peroleh dari hasil wawancara dengan pihak pihak yang terkait. Wawancara, menurut Moleong (2002) adalah percakapan dengan maksud tertentu. Percakapan ini dilakukan dengan mengajukan pertanyan-pertanyaan secara lisan maupun tulisan yang sebelumnya telah disusun sedemikian rupa untuk memenuhi kebutuhan data. Instrumen yang digunakan dapat berupa daftar pertanyaan juga alat perekam suara dan gambar.

- Dokumentasi, data yang diperoleh berasal dari arsip atau dokumen milik instansi terkait. Setelah data terkumpul, kemudian dilakukan pengolahan dan analisis.

Proses yang akan dilakukan pada penelitian ini adalah:

- Identifikasi Proses Pengolahan Biji Jarak. Identifikasi terhadap proses pengolahan biji jarak dilakukan pada awal penelitian. Identifikasi proses meliputi proses pengolahan biji jarak kering menjadi minyak jarak, serta proses pengolahan minyak jarak menjadi biodiesel. Identifikasi proses ini bertujuan mengetahui setiap aktivitas pada proses pengolahan.
- Penentuan Jumlah Aktivitas Dan Biaya Aktivitas Pada Proses Pengolahan Biji Jarak. Setelah proses identifikasi, dilakukan penentuan jumlah aktivitas dalam proses pengolahan biji jarak. Disamping penentuan aktivitas, dilakukan pula penentuan biaya aktivitas. Biaya aktivitas ini adalah biaya-biaya yang timbul pada setiap aktivitas proses.

- Penentuan Kos Aktivitas Produk (Biodiesel) Dengan Metode Activity-Based Object Costing. Aktivitas serta biaya aktivitas yang diperoleh pada proses sebelumnya kemudian diolah menggunakan metode Activity-Based Object Costing. Pengolahan dilakukan untuk memperoleh harga biodiesel sesuai dengan metode Activity-Based Object Costing.

- Penentuan Harga Biodiesel Dengan Kesetaraan Harga Minyak Solar. Terakhir, dilakukan penyetaraan harga biodiesel dengan metode Activity-Based Object Costing terhadap harga minyak diesel untuk industri di Nusa Penida. Penyetaraan ini juga memproses kembali harga biodiesel tersebut untuk mendapatkan harga biji jarak kering yang sesuai dengan proses pengolahan menggunakan Activity-Based Object Costing.

Secara umum, gambaran proses perhitungan dalam Activity-Based Cost System digambarkan pada Gambar 1.

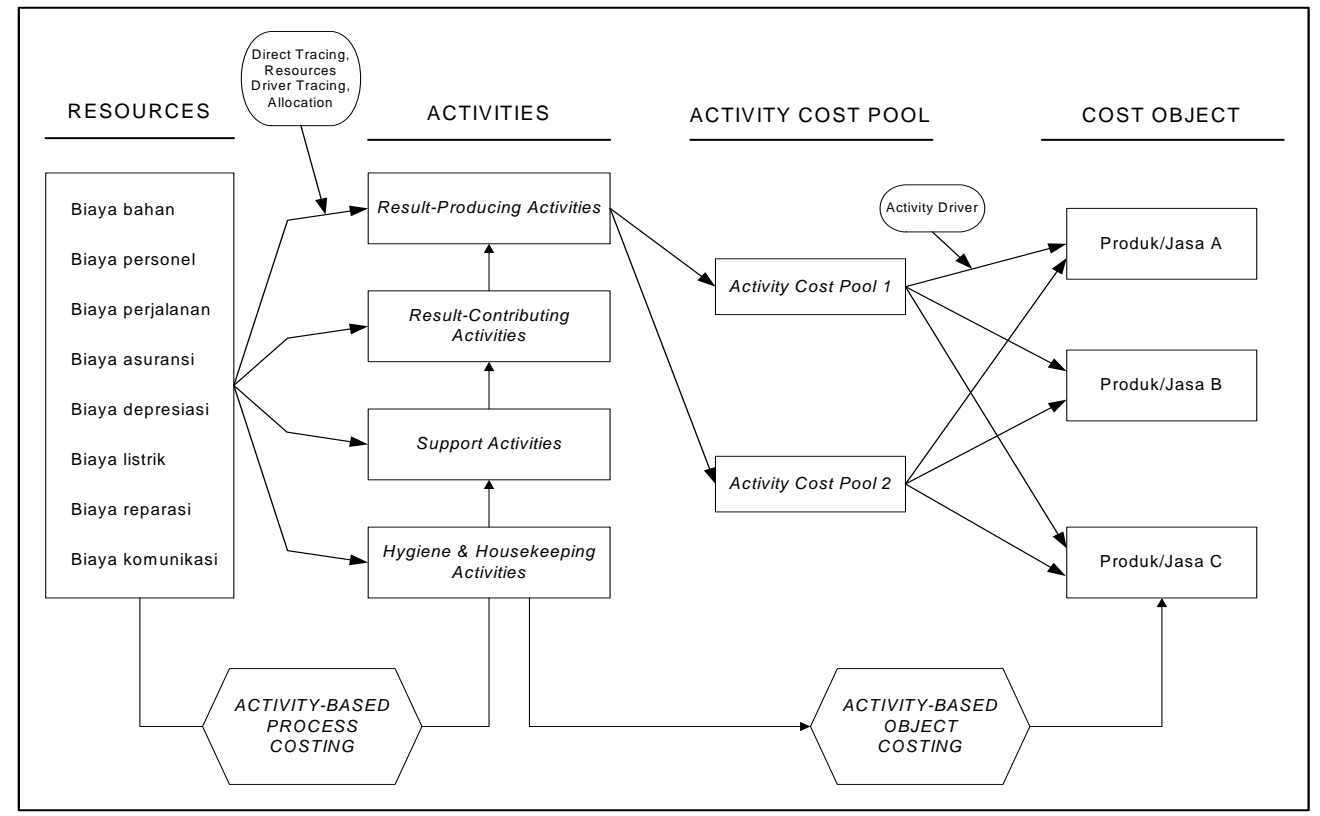

Gambar 1: Rerangka Proses Pengolahan Data dalam Activity-Based Cost System

\section{HASIL DAN PEMBAHASAN}

Proses pembuatan biodiesel dari biji jarak ada dua tahap yaitu tahap pembuatan minyak jarak serta pengolahan minyak jarak menjadi biodiesel.

- $\quad$ Tahap Pembuatan Minyak Jarak

Secara umum, proses pembuatan minyak jarak adalah dengan mengekstraksi biji jarak yang telah kering. Proses ekstraksi ini Radha Kurniawan : Penentuan Harga Jual Biji... dapat dilakukan dengan metode mekanis maupun dengan metode ekstraksi dengan pelarut. Kebanyakan di Indonesia, ekstraksi menggunakan metode mekanis dengan bantuan mesin pengepres.

- $\quad$ Tahap Pembuatan Biodiesel

Sedangkan pembuatan biodiesel dengan menggunakan base oil minyak jarak dilakukan dalam beberapa tahap.

p-ISSN:1693 - 2951; e-ISSN: 2503-2372 
- Mixing pertama merupakan proses pencampuran metal alkohol (methanol) dengan $\mathrm{NaOH}$ sampai keduanya larut. Hasil dari pencampuran ini dinamakan methoksid. Dilakukan proses pemanasan base oil dengan memblender minyak. Pengadukan ini akan menaikkan suhu minyak menjadi $50-55^{\circ} \mathrm{C}$. Untuk mencapai suhu tersebut, diperlukan waktu sekitar 15-20 menit.

- Mixing kedua yaitu mereaksikan hasil mixing pertama (methoksid) dengan menuangkannya ke dalam minyak yang telah dipanaskan hingga bersuhu $50^{\circ} \mathrm{C}$ yang masih ada di dalam blender. Proses mixing dilakukan selama 30-60 menit dengan kecepatan rendah.

- Settling dilakukan dengan menuangkan ke dalam wadah dan didiamkan selama 12-24 jam. Disini biodiesel sudah terpisah dengan gliserin yang mengendap di dasar wadah.

- Dilanjutkan dengan proses pemisahan (separating), memisahkan biodiesel dengan gliserin.

- Netralisasi dan destilasi. Tujuan netralisasi adalah untuk memudahkan proses pencucian. Biodiesel yang bersifat terlalu basa akan menghasilkan banyak sabun saat dicuci. Untuk menetralkannya, maka ditambahkan larutan asam.

- Pencucian dan pengeringan. Biodiesel untuk dapat digunakan dengan baik harus dicuci. Pencucian dilakukan dengan menggunakan air, dimana perlu dicampur dengan air untuk melarutkan sisa katalis, sabun, gliserin, dan methanol yang terperangkap dalam biodiesel tersebut.

- Langkah terakhir adalah penghilangan air (dehydration). Proses dehydration ini bertujuan untuk menghilangkan kadar air dalam biodiesel. Proses ini dilakukan dengan memanaskan biodiesel. Setelah proses ini, biodiesel dapat digunakan.

Analisa dengan metode Activity Based-cost System dapat menggunakan simulasi sebuah perusahaan pengolahan biodiesel. Analisa dilakukan terhadap biaya-biaya baik biaya tetap maupun biaya variabel. Biaya tetap adalah biaya yang jumlahnya tidak tergantung dengan perubahan jumlah barang yang diproduksi misalnya biaya pemasaran dan biaya administrasi. Sedangkan biaya variabel adalah biaya yang timbul yang dapat berubah sesuai dengan jumlah produk yang dihasilkan.

Menurut Erliza Hambali dkk (2007), biaya tetap yang dikeluarkan oleh industri biodiesel setiap bulannya sebesar Rp. 15.600.000. Sedangkan biaya variabel yang dikeluarkan untuk memproduksi 25.200 liter biodiesel per bulan sebesar Rp. 102.203.000. Sedangkan biaya produksi dan biaya-biaya tiap divisi diolah seperti dalam Tabel 1.

TABEL I

DATA PRODUKSI, DIVISI, DAN OVERHEAD

\begin{tabular}{|c|c|c|c|c|c|}
\hline \multicolumn{6}{|l|}{ Data Produksi } \\
\hline \multicolumn{2}{|c|}{ Unit yang diproduksi per tahun } & \multicolumn{4}{|c|}{302.400 liter } \\
\hline \multicolumn{2}{|l|}{ Biaya utama } & \multicolumn{4}{|c|}{ Rp. 1.156.596.000 } \\
\hline \multicolumn{2}{|c|}{ Jam tenaga kerja langsung (TKL) } & \multicolumn{4}{|c|}{29.952 jam } \\
\hline \multicolumn{2}{|l|}{ Jam mesin } & \multicolumn{4}{|c|}{9.984 jam } \\
\hline Data Divisi & $\begin{array}{c}\text { Divisi Pengolahan Biji } \\
\text { Jarak }\end{array}$ & \multicolumn{2}{|c|}{$\begin{array}{c}\text { Divisi Pengolahan Minyak } \\
\text { Jarak }\end{array}$} & \multicolumn{2}{|r|}{ Jumlah } \\
\hline Solar/Listrik & Rp. 6.504 .000 & \multicolumn{2}{|r|}{ Rp. 14.400 .000} & \multicolumn{2}{|c|}{ Rp. 20.904 .000} \\
\hline Total & Rp. 6.504 .000 & \multicolumn{2}{|r|}{ Rp. 14.400 .000} & \multicolumn{2}{|c|}{ Rp. 20.904.000 } \\
\hline \multicolumn{6}{|c|}{ Data Jam Produksi } \\
\hline \multirow{2}{*}{ Keterangan } & \multicolumn{4}{|c|}{ Divisi } & \multirow{2}{*}{ Jumlah } \\
\hline & \multicolumn{2}{|c|}{ Pengolahan Biji Jarak } & \multicolumn{2}{|c|}{ Pengolahan Minyak Jarak } & \\
\hline $\begin{array}{l}\text { Jam TKL } \\
\text { Jam Mesin }\end{array}$ & \multicolumn{2}{|c|}{$\begin{array}{c}9.984 \text { jam } \\
5.821,2 \text { jam }\end{array}$} & \multicolumn{2}{|l|}{$\begin{array}{l}19.968 \text { jam } \\
4.162,8 \text { jam }\end{array}$} & $\begin{array}{l}29.952 \text { jam } \\
9.984 \text { jam }\end{array}$ \\
\hline
\end{tabular}


Majalah Ilmiah Teknologi Elektro, Vol. 18, No. 2, Mei - Agustus 2019

DOI: https://doi.org/10.24843/MITE.2019.v18i02.P05

Analisa Harga Pokok Produksi Dengan Metode Tradisional

Perhitungan harga pokok produksi dengan menggunakan metode tradisional banyak diterapkan di masyarakat karena perhitungan yang sederhana. Biaya unit produk dihitung dengan rincian jumlah biaya dibagi dengan jumlah jam tenaga kerja langsung (TKL) menghasilkan tarif berikut :

$=\frac{\text { Rp. 1.177.502.246 }}{302.400 \text { liter }}=$ Rp.3.893,9 / liter

Tarif Pabrik $=\frac{\text { Rp.20.904.000 }}{29.952 \mathrm{jam}}=\mathrm{Rp} \cdot 698 / \mathrm{jam}$ TKL

Perhitungan biaya dihitung di tiap-tiap divisi. Perhitungan dilakukan dengan mengalikan tarif pabrik dengan jam tenaga kerja tiap-tiap divisi.

- Divisi Pengolahan Biji Jarak :

Rp. 698 x 9.984 jam = Rp. 6.968 .832

- $\quad$ Divisi Pengolahan Minyak Jarak :

Rp. 698 x 19.968 jam = Rp. 13.937.664
Dengan demikian, jumlah biaya produksi secara keselurahan adalah :

= Jumlah biaya utama + Biaya tiap divisi

= Rp. 1.156.596.000 + Rp. 6.968.832 + Rp. 13.937.664

$=$ Rp. 1.177.502.496

Untuk menentukan harga pokok produksi, dilakukan perhitungan dengan membagi jumlah biaya produksi dengan jumlah unit produksi.

$=\frac{\text { Rp. } 1 \cdot 177 \cdot 502 \cdot 246}{302 \cdot 400 \text { liter }}=$ Rp.3.893,9 / liter

Jadi, harga pokok produksi per liter biodiesel jika dihitung dengan metode tradisional adalah Rp. 3.893,9 per liter.

\section{Analisa Harga Pokok Produksi Dengan Metode Activity-Based Cost System}

Sistem perhitungan harga pokok menggunakan Activity-Based Cost System pada dasarnya adalah perhitungan biaya dengan memperhatikan aktivitas, dimana dilakukan penelusuran biaya-biaya pada aktivitas, kemudian biaya pada produk. Secara umum, proses perhitungan harga pokok menggunakan Activity-Based Cost System dapat digambarkan sebagai berikut.

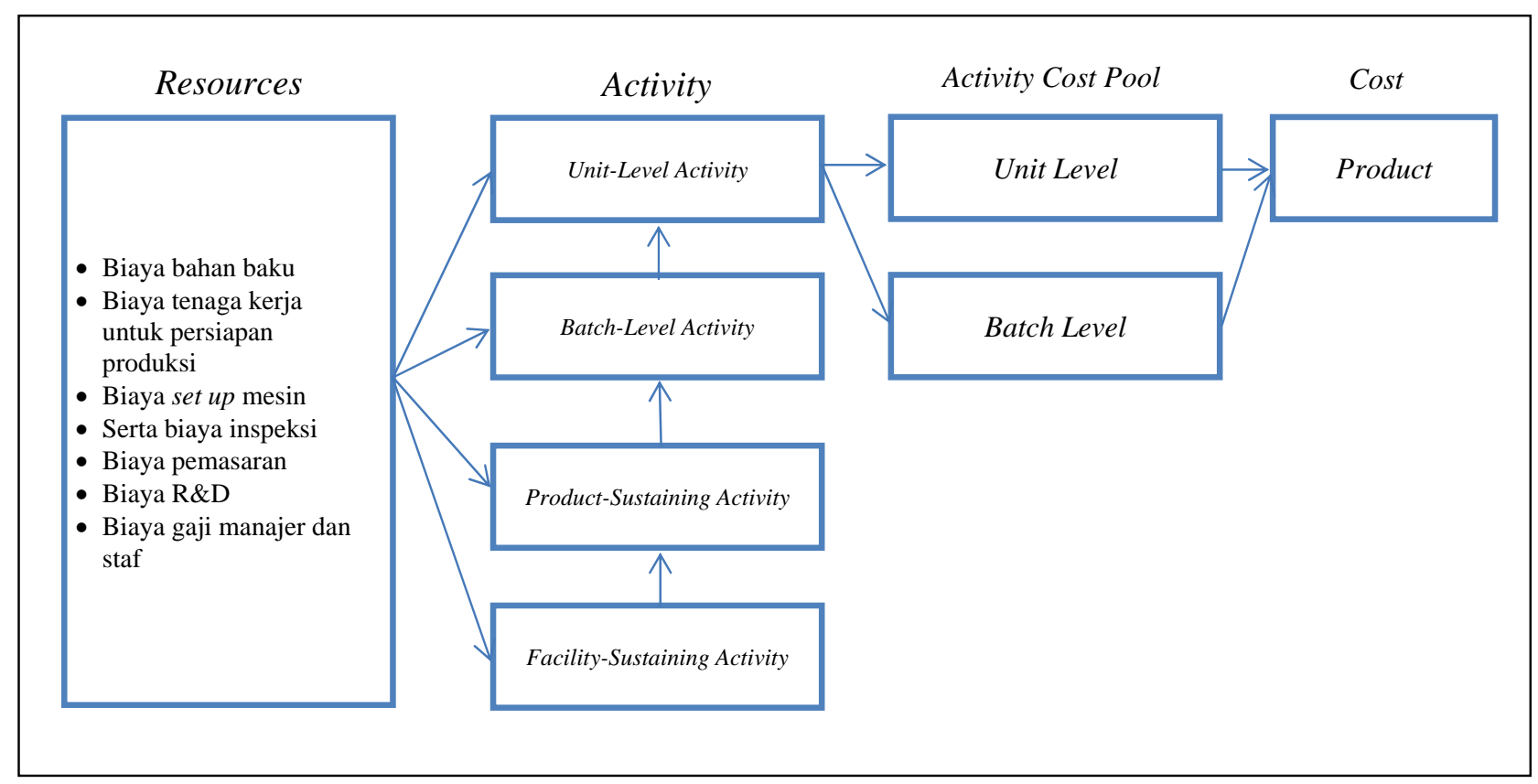

Gambar 2: Skema Perhitungan Harga Pokok Produksi Dengan Metode Activity-Based Cost System

Radha Kurniawan : Penentuan Harga Jual Biji...

p-ISSN:1693 - 2951; e-ISSN: 2503-2372 
Berdasarkan metode Activity Based-cost System, biaya-biaya dari proses pengolahan dapat digolongkan sebagai berikut :

\section{Unit-Level Activity}

Aktivitas yang berhubungan langsung dengan setiap unit produk, termasuk di dalamnya adalah biaya bahan baku yakni biji jarak kering, methanol, $\mathrm{KOH}$, solar, listrik + air, biaya tenaga kerja dan kemasan drum.

Biaya Bahan Baku termasuk di dalamnya biji jarak kering, methanol, $\mathrm{KOH}$, dan kemasan drum, dihitung dengan pembagian biaya total bahan baku dibagi dengan jumlah produksi.

$$
=\frac{\text { Rp. 1.064.196.000 }}{302.400 \text { liter }}=\text { Rp. 3.519,17 / liter }
$$

Sedangkan untuk biaya tenaga kerja per jam, biaya diolah dari biaya tenaga kerja per bulan dengan perhitungan :

Biaya tenaga kerja per bulan : Rp. 7.200.000

Jumlah jam kerja per bulan : 8 jam kerja per hari x 26 hari kerja per bulan $\mathrm{x} 12$ orang $=208$ jam kerja per bulan. Jadi biaya tenaga kerja per jam adalah

$=\frac{\text { Rp. } 7.200 .000}{2.496 \text { jam }}=$ Rp. $2.884 /$ jam

Batch-Level Activity

Aktivitas yang dilakukan untuk masing-masing batch atau kelompok produk, atau mengeset pekerjaan yang akan dilakukan. Biaya yang termasuk disini adalah biaya tenaga kerja kerja untuk persiapan produksi, biaya set up mesin, serta biaya inspeksi.

Persiapan produksi,set up mesin, serta inspeksi dilakukan dalam menit. Jika dikonversikan ke dalam rupiah berdasarkan biaya tenaga kerja per jam, maka biaya per menit adalah :

= Biaya Tenaga Kerja Langsung per jam

$$
60 \text { menit }
$$

$=\frac{\text { Rp. } 2.884}{60}=$ Rp. $48 /$ menit

\section{Product-Sustaining Activity}

Aktivitas yang dilakukan untuk mendukung produksi yang berbeda, termasuk disini adalah biaya pemasaran dan juga biaya R\&D (Research \& Development)

Facility-Sustaining Activity

Aktivitas yang dilakukan untuk mendukung produksi secara umum dan berhubungan dengan kegiatan yang mempertahankan kapasitas perusahaan. Termasuk disini adalah biaya ATK, biaya telepon dan biaya karyawan kunci perusahaan yakni biaya gaji manajer dan staf. Data yang digunakan sama dengan data pada perhitungan harga pokok produksi dengan metode tradisional. Sedangkan aktivitas overhead yang teridentifikasi pada perusahaan pengolahan biodiesel ini adalah :

1. Persiapan (set up) mesin

2. Daya (listrik, solar, dan air)

3. Inspeksi

Biaya yang ditimbulkan dari aktivitas di atas disebut biaya overhead. Biaya overhead adalah biaya yang terjadi atau dibebankan dalam proses produksi selain biaya bahan baku dan biaya tenaga kerja langsung (Mursyidi, 2008:221). Adanya identifikasi aktivitas ini membuat perhitungan biaya overhead tiap divisi mengalami penyesuaian. Penyesuaian ini dipaparkan dalam Tabel II berikut.

TABEL II

ALOKASI WAKTU AKTIVITAS TIAP BATCH

\begin{tabular}{|l|c|c|c|}
\hline $\begin{array}{c}\text { Keterangan } \\
\text { Aktivitas }\end{array}$ & $\begin{array}{c}\text { Divisi } \\
\text { Pengolahan } \\
\text { Biji Jarak } \\
\text { (menit) }\end{array}$ & $\begin{array}{c}\text { Divisi } \\
\text { Pengolahan } \\
\text { Minyak } \\
\text { Jarak } \\
\text { (menit) }\end{array}$ & $\begin{array}{c}\text { Jumlah } \\
\text { (menit) }\end{array}$ \\
\hline Persiapan & 5 & 10 & 15 \\
\hline Set up Mesin & 5 & 15 & 20 \\
\hline Inspeksi & 5 & 15 & 20 \\
\hline Total & 15 & 40 & 55 \\
\hline
\end{tabular}

Dari alokasi waktu tersebut, dihitung biayanya menggunakan pengali biaya tenaga kerja langsung per menit yaitu Rp. 48/menit kemudian dikalikan dengan jumlah tenaga kerja di tiap divisi. Seperti disebutkan di uraian perusahaan, divisi pengolahan biji jarak memiliki 4 orang staf, sedangkan divisi pengolahan minyak jarak memiliki 8 orang staf. Dengan demikian maka biaya overhead tiap aktivitas sesuai dengan Tabel III.

TABEL III

BIAYA OVERHEAD TIAP AKTIVITAS

\begin{tabular}{|l|c|c|}
\hline $\begin{array}{c}\text { Keterangan } \\
\text { Aktivitas }\end{array}$ & $\begin{array}{c}\text { Divisi } \\
\text { Pengolahan Biji } \\
\text { Jarak }\end{array}$ & $\begin{array}{c}\text { Divisi } \\
\text { Pengolahan } \\
\text { Minyak Jarak }\end{array}$ \\
\hline Persiapan & Rp. 960 & Rp. 3.840 \\
\hline Set up Mesin & Rp. 960 & Rp. 5.760 \\
\hline Inspeksi & Rp. 960 & Rp. 5.760 \\
\hline
\end{tabular}

Biaya-biaya tersebut kemudian dikalikan dengan jumlah batch produksi per tahunnya yakni 3.024 batch sehingga total biaya overhead tiap aktivitas tercantum dalam Tabel IV berikut.

TABEL IV

BIAYA OVERHEAD TIAP AKTIVITAS DiKALIKAN JUMLAH BATCH

\begin{tabular}{|c|c|c|c|}
\hline $\begin{array}{c}\text { Keterangan } \\
\text { Aktivitas }\end{array}$ & $\begin{array}{c}\text { Divisi } \\
\text { Pengolahan } \\
\text { Biji Jarak } \\
\text { (Rp) }\end{array}$ & $\begin{array}{c}\text { Divisi } \\
\text { Pengolahan } \\
\text { Minyak } \\
\text { Jarak (Rp.) }\end{array}$ & $\begin{array}{c}\text { Jumlah } \\
\text { (Rp.) }\end{array}$ \\
\hline Solar/Listrik & 6.504 .000 & 14.400 .000 & 20.904 .000 \\
\hline Persiapan & 2.903 .040 & 11.612 .160 & 14.515 .200 \\
\hline $\begin{array}{c}\text { Set up } \\
\text { Mesin }\end{array}$ & 2.903 .040 & 17.418 .240 & 20.321 .280 \\
\hline Inspeksi & 2.903 .040 & 17.418 .240 & 20.321 .280 \\
\hline Total & 15.213 .120 & 60.848 .640 & 76.061 .760 \\
\hline
\end{tabular}

Secara keseluruhan, biaya-biaya yang timbul dari aktivitas yang telah teridentifikasi pada perusahaan dapat dirangkum seperti pada Tabel V.

TABEL V

RANGKUMAN BIAYA AKTIVITAS

\begin{tabular}{|l|l|}
\hline \multicolumn{2}{|c|}{ Data Pabrik } \\
\hline Unit yang diproduksi per tahun & 302.400 liter \\
\hline
\end{tabular}




\begin{tabular}{|c|c|c|c|}
\hline \multicolumn{2}{|c|}{$\begin{array}{l}\text { Biaya utama per tahun } \\
\text { Jam tenaga kerja langsung } \\
\text { Jam mesin }\end{array}$} & \multicolumn{2}{|c|}{$\begin{array}{l}\text { Rp. } 1.156 .596 .000 \\
29.952 \text { jam } \\
9.984 \text { jam }\end{array}$} \\
\hline \multicolumn{4}{|c|}{ Data Divisi } \\
\hline Keterangan & $\begin{array}{c}\text { Divisi } \\
\text { Pengolahan } \\
\text { Biji Jarak }\end{array}$ & $\begin{array}{l}\text { Divisi } \\
\text { Pengolahan } \\
\text { Minyak } \\
\text { Jarak } \\
\end{array}$ & Jumlah \\
\hline $\begin{array}{l}\text { Jam TKL } \\
\text { Jam Mesin }\end{array}$ & $\begin{array}{l}9.984 \text { jam } \\
4992 \text { jam }\end{array}$ & $\begin{array}{c}19.968 \text { jam } \\
4992 \text { jam }\end{array}$ & $\begin{array}{c}29.952 \text { jam } \\
9.984 \text { jam }\end{array}$ \\
\hline \multicolumn{4}{|c|}{ Biaya Overhead } \\
\hline Solar/Listrik & $\begin{array}{c}\text { Rp. } \\
6.504 .000\end{array}$ & $\begin{array}{c}\text { Rp. } \\
14.400 .000\end{array}$ & $\begin{array}{c}\text { Rp. } \\
20.904 .000\end{array}$ \\
\hline Persiapan & $\begin{array}{c}\text { Rp. } \\
\text { 2.903.040 }\end{array}$ & $\begin{array}{c}\text { Rp. } \\
11.612 .160\end{array}$ & $\begin{array}{c}\text { Rp. } \\
14.515 .200\end{array}$ \\
\hline Set up Mesin & $\begin{array}{c}\text { Rp. } \\
\text { 2.903.040 }\end{array}$ & $\begin{array}{c}\text { Rp. } \\
17.418 .240\end{array}$ & $\begin{array}{c}\text { Rp. } \\
20.321 .280\end{array}$ \\
\hline Inspeksi & $\begin{array}{c}\text { Rp. } \\
\text { 2.903.040 }\end{array}$ & $\begin{array}{c}\text { Rp. } \\
\text { 17.418.240 }\end{array}$ & $\begin{array}{c}\text { Rp. } \\
\text { 20.321.280 }\end{array}$ \\
\hline Total & $\begin{array}{c}\text { Rp. } \\
15.213 .120\end{array}$ & $\begin{array}{c}\text { Rp. } \\
60.848 .640\end{array}$ & $\begin{array}{c}\text { Rp. } \\
76.061 .760\end{array}$ \\
\hline
\end{tabular}

3. Daya (listrik, solar, dan air), dengan pendorong aktivitas adalah jam mesin,

4. Inspeksi, dengan pendorong aktivitas adalah jam tenaga kerja langsung

Dari aktivitas tersebut di atas dapat dikelompokkan berdasarkan kaitannya dalam proses produksi. Aktivitas persiapan, set up mesin, serta inspeksi dilakukan setiap kali sekelompok (batch) produk dihasilkan. Sedangkan aktivitas daya solar/listrik dilakukan setiap kali produk dihasilkan.

Jadi biaya overhead tersebut dapat diringkas ke dalam dua set aktivitas yaitu :

1. Set dengan daya solar/listrik disebut kelompok tingkat unit yakni

- $\quad$ Total biaya daya solar/listrik = Rp. 20.904.000

- $\quad$ Jam mesin = 9.984 jam

- $\quad$ Tarif Kelompok (biaya per jam mesin) = Rp. 2.094

2. Set dengan persiapan, set up mesin, dan inspeksi disebut kelompok tingkat batch yaitu

- Total Biaya Persiapan = Rp. 14.515.200

- $\quad$ Total Biaya Set up mesin = Rp. 20.321.280

- $\quad$ Total Biaya Inspeksi = Rp. 20.321.280

- $\quad$ Total Biaya Kelompok = Rp. 55.157.760

- Jam Tenaga Kerja Langsung = 29.952 jam

- $\quad$ Tarif Kelompok = Rp. 1.841,53

aktivitas. Perhitungan biaya berdasarkan aktivitas sangat berkaitan dengan aktivitas-aktivitas yang ada. Langkah awal yakni identifikasi aktivitas, memerlukan pembuatan daftar semua jenis pekerjaan, misalnya penanganan bahan, persiapan, set up mesin, inspeksi, ataupun perbaikan produk. Perusahaan dapat menentukan biaya-biaya dari setiap aktivitas, kemudian juga menentukan pendorong aktivitas yang dikaitkan dengan setiap aktivitas dan kemudian menghitung tarif overhead masing-masing aktivitas tersebut.

Untuk mengurangi jumlah tarif overhead sekaligus untuk merampingkan proses, aktivitas dikelompokkan ke dalam setset homogen berdasarkan karakteristik yang serupa, yakni misalnya aktivitas-aktivitas yang secara logika terkait, maupun aktivitas yang memiliki perbandingan konsumsi yang sama untuk semua produk. Dalam set-set homogen tersebut, biaya tiap aktivitas dijumlahkan. Setelah kelompok biaya ditentukan, biaya per satuan pendorong aktivitas dihitung dengan membagi biaya kelompok dengan kapasitas praktis pendorong aktivitas. Biaya ini disebut biaya kelompok, dimana perhitungan ini mengakhiri tahapan pertama. Secara keseluruhan, tahap pertama menghasilkan keluaran :

- Aktivitas teridentifikasi

- Biaya dibebankan pada setiap aktivitas

- Aktivitas yang berkaitan dikelompokkan bersama membentuk set homogen

- Biaya dari kelompok aktivitas dijumlahkan untuk menentukan kelompok biaya homogen

- Tarif (overhead) kelompok dihitung.

Aktivitas overhead yang teridentifikasi pada perusahaan pengolahan biodiesel ini adalah:

1. Persiapan, dengan pendorong aktivitas adalah jam tenaga kerja langsung,

2. Set up mesin, dengan pendorong aktivitas adalah jumlah batch,

Radha Kurniawan : Penentuan Harga Jual Biji...

Pada tahap kedua, biaya untuk masing-masing kelompok overhead ditelusuri ke produk. Hal ini dilakukan dengan menggunakan tarif kelompok yang dihitung pada tahap pertama dan dengan mengukur jumlah sumber daya yang digunakan oleh produk. Jadi, overhead yang dibebankan dari setiap biaya kelompok ke produk dihitung sebagai

Overhead yang dibebankan $=$ tarif kelompok $\mathrm{x}$ penggunaan aktivitas

Karena jenis produk yang diproduksi hanya satu yakni biodiesel, maka biaya overhead langsung didapat dari perkalian antara 187tarif kelompok dengan penggunaan aktivitas. Perhitungan tersebut ada pada Tabel VI berikut.

TABEL VI

Perhitungan Biaya Unit

\begin{tabular}{|c|c|}
\hline Biaya Utama & Rp. 1.156.596.000 \\
\hline $\begin{array}{l}\text { Biaya Overhead } \\
\bullet \quad \text { Kelompok tingkat unit } \\
\text { (Rp. 2.093,75 x } 9.984 \text { jam mesin) } \\
\bullet \quad \text { Kelompok tingkat batch } \\
\text { (Rp. } 1.841 .53 \text { x } 29.952 \text { jam TKL) }\end{array}$ & $\begin{array}{l}\text { Rp. } 20.904 .000 \\
\text { Rp. } 55.157 .760\end{array}$ \\
\hline $\begin{array}{l}\text { Jumlah Biaya Produksi } \\
\text { (Biaya utama + biaya overhead) }\end{array}$ & Rp. 1.232.657.760 \\
\hline Unit Produksi & 302.400 liter \\
\hline $\begin{array}{l}\text { Biaya unit } \\
\text { (Jumlah biaya produksi / unit } \\
\text { produksi) }\end{array}$ & Rp. 4.076,25 \\
\hline
\end{tabular}

Jadi, biaya per unit dihitung menggunakan Activity-Based Cost System adalah sebesar Rp. 4.076,25 per liter biodiesel.

$$
\text { p-ISSN:1693 - 2951; e-ISSN: 2503-2372 }
$$


Terdapat perbedaan harga jika dihitung dengan metode tradisional yakni Rp. 3.893,9 per liter, dengan selisih sebesar Rp. 182,35 per liter biodiesel.

Harga pokok produksi tersebut masih perlu ditambah dengan biaya-biaya di level Product-sustaining activity dan facilitysustaining activity yakni biaya-biaya pemasaran, gaji karyawan kunci, dan lain-lain.

Product-sustaining activity

- Biaya pemasaran Rp. 60.000 .000

- Biaya $R \& D \quad$ Rp. 12.000 .000

Total Biaya Product-sustaining activity per tahun sebesar Rp. 72.000 .000 .

Facility-sustaining activity

- Biaya Alat Tulis Kantor Rp. 7.200.000

- Biaya Telepon Rp. 12.000.000

- Biaya Gaji Manajer Rp. 42.000.000

- Biaya Gaji 3 Staff Rp. 54.000.000

Total biaya Facility-sustaining activity per tahun sebesar Rp. 115.200.000

Total Biaya : : Rp. 187.200.000

Unit Produksi : 304.200 liter

Biaya tambahan (total biaya / unit produksi) : Rp. 619,04 per liter. Dengan adanya tambahan biaya tersebut, maka harga pokok produksi secara keseluruhan adalah :

Rp. 4.076,25 + Rp. 619,04 = Rp. 4.695,3 per liter. Dengan harga pokok produksi sebesar Rp. 4.695,3 per liter dan margin keuntungan yang diharapkan sebesar $\pm 20 \%$, maka harga jual biodiesel akan berada di Rp. 5.635 per liter.

\section{Penyetaraan Harga Jual Biodiesel Dengan Minyak Solar}

Biodiesel yang diposisikan sebagai pengganti minyak solar, perlu disetarakan baik dari segi kualitas maupun harga. Untuk wilayah Bali serta Nusa Penida, terdapat perbedaan harga jual minyak solar non subsidi. Perbedaan ini dikarenakan biaya transportasi tambahan dari pulau Bali ke pulau Nusa Penida sebesar Rp 955,- per liter. Berdasarkan data PLN tahun 20152016, harga rata-rata minyak solar non subsidi yang didapat dari Pertamina adalah sebesar Rp. 6.844/liter.

Dengan harga rata-rata solar sebesar Rp. 6.844 per liter, maka harga ini yang akan menjadi harga penyetaraan biodiesel. Jika harga jual biodiesel sebesar Rp. 6.844 per liter, dengan margin keuntungan $\pm 20 \%$, maka harga pokok produksinya adalah sebesar :

Rp. $6.844 \times \frac{100}{120}=$ Rp. 5.703

Penentuan harga biji jarak kering per kilogram tidak mengubah komposisi biaya-biaya yang ada yaitu biaya overhead, biaya tambahan pada product-sustaining activity serta biaya pada facility sustaining activity.Penyesuaian hanya pada biaya utama dimana pada biaya utama terdapat biaya pembelian biji jarak pagar. Penentuan harga pokok produksi (HPP) berdasarkan activity based cost system adalah : $\mathrm{HPP}=$

Biaya Utama+Biaya Overhead+Biaya Product and Facility

Unit Produksi
Biaya utama merupakan biaya bahan pokok yang termasuk biaya biji kering jarak pagar, biaya methanol, biaya $\mathrm{KOH}$, serta biaya kemasan drum. Dengan demikian, penentuan biaya utama dapat dilakukan dengan perhitungan :

(Biaya Utama + Biaya Overhead + Biaya Product \& Facility) $=($ HPP $x$ Unit Produksi $)$

Jika dikonversi, maka persamaannya menjadi

Biaya Utama $=($ HPP x Unit Produksi $)-$ Biaya Overhead Biaya Product \& Facility

Dengan demikian, jika angka-angka jumlah produksi, HPP, serta biaya-biaya disubstitusikan ke dalam persamaan tersebut, maka akan menjadi :

Biaya Utama $=($ Rp. 5.703 x 302.400 liter $)-($ Rp. 116.854 .008

+ Rp. 187.200.000)

Biaya Utama $=($ Rp. 1.724.688.000 $)-($ Rp. 304.054.008 $)$

Biaya Utama $=$ Rp. 1.420.633.992

Dari perhitungan tersebut didapatkan jumlah biaya utama dari harga pokok produksi Rp. 5.703 atau setara dengan harga solar non subsidi adalah sebesar Rp. 1.420.633.992. Biaya utama ini merupakan biaya campuran antara biaya biji kering jarak pagar, biaya methanol, biaya $\mathrm{KOH}$, serta biaya kemasan drum. Karena tidak ada perubahan komposisi bahan, maka biaya-biaya selain biaya biji kering jarak pagar juga tidak mengalami perubahan.

Jika biaya utama sebesar Rp. Rp. 1.420.633.992, biaya methanol sebesar Rp. 96.768.000, biaya KOH sebesar Rp. 37.428.000, dan biaya kemasan drum sebesar Rp. 100.800.000, maka biaya biji kering jarak pagar sebesar :

Biaya Utama = Biaya Biji Jarak + Biaya $\mathrm{KOH}+$ Biaya Methanol + Biaya Drum

Rp.1.420.633.992 = Biaya Biji Jarak + Rp. 37.428.000 + Rp.96.768.000 + Rp.100.800.000

Rp. 1.420.633.992 = Biaya Biji Jarak + Rp. 234.996.000

Biaya Biji Jarak = Rp. 1.420.633.992 - Rp. 234. 996.000

Biaya Biji Jarak = Rp. 1.185.637.992

Jadi, biaya biji jarak secara keseluruhan adalah Rp. 1.185.637.992. Jika jumlah biji kering jarak pagar yang digunakan adalah sebanyak 96 ton atau $96.000 \mathrm{~kg}$ per bulan atau $1.152 .000 \mathrm{~kg}$ per tahun, maka harga beli biji jarak per kilogram adalah :

Harga per kg biji kering jarak pagar $=\frac{\text { Rp. } 1.185 .637 .992}{1.152 .000 \mathrm{~kg}}$

Harga biji kering jarak pagar = Rp. 1.028 per kg

\section{KESIMPULAN}


Majalah Ilmiah Teknologi Elektro, Vol. 18, No. 2, Mei - Agustus 2019

DOI: https://doi.org/10.24843/MITE.2019.v18i02.P05

Kesimpulan dari penelitian ini adalah :

1. Dari hasil perhitungan, didapatkan harga pokok produksi biodiesel jika dihitung dengan metode Activity-Based Cost System sebesar Rp. 4.076,25 per liter. Jika ditambahkan biaya-biaya di level Productsustaining activity dan Facility-sustaining activity, secara keseluruhan harga pokok produksi adalah sebesar Rp. 4.695,3 per liter.

2. Harga pokok produksi sebesar Rp. 4.695,3 per liter tersebut adalah dengan menggunakan harga bakan baku biji kering jarak pagar seharga Rp. 800/kg. Jika harga biodiesel disetarakan dengan harga solar non industri rata-rata untuk wilayah Nusa Penida sebesar Rp. 6.844 per liter, maka harga biji jarak kering adalah Rp.1.028/kg. Angka ini lebih tinggi dari harga beli PLN sebesar Rp. 500/kg. Harga ini pula dapat menjadi alternatif harga jual biji kering jarak pagar yang wajar sehingga mampu meningkatkan kesejahteraan petani jarak pagar.

Saran-saran yang dapat diberikan terkait dengan penelitian ini adalah:

1. Para pengusaha pengolahan biodiesel berbasis minyak jarak dapat lebih memperhatikan kesejahteraan petani biji jarak dengan lebih memberikan nilai kepada harga jual biji jarak di tingkat petani.

2. Penerapan Activity-Based Cost System dalam penetapan harga jual biodiesel akan lebih efektif lagi bila perusahaan memproduksi lebih dari satu jenis biodiesel mengingat sistem perhitungan dengan Activity-Based Cost System memungkinkan untuk menghitung harga beberapa produk dalam satu perusahaan.

\section{REFERENSI}

[1] I Ketut Ardana, Bambang Pramudya, Maharani Hasanah, Armansyah H. Tambunan, Pengembangan Tanaman Jarak Pagar (Jatropha Curcas L) Mendukung Kawasan Mandiri Energi Di Nusa Penida, Bali, Institut Pertanian Bogor, 2008

[2] Hambali, Erliza. Prospek Pengembangan Tanaman Jarak Pagar Untuk Biodiesel dan Produk Turunan Lainnya, Pusat Penelitian Surfaktan dan Bioenergi LPPM-IPB

[3] Kementrian Energi Dan Sumber Daya Mineral, Master Plan Pembangunan Ketenagalistrikan 2010 S.D. 2014, www.esdm.go.id Diakses 9 Januari 2011

[4] Kementrian Energi Dan Sumber Daya Mineral, Perkembangan Harga BBM 2009. www.esdm.go.id diakses Desember 2010

[5] Yuni Astuti, Budidaya Dan Manfaat Jarak Pagar (Jatropha Curcas L ), Universitas Mercu Buana

[6] Arikunto, Suharsimi. Prosedur Penelitian, Suatu Pendekatan Praktek. Rineka Cipta. Bandung 2002

[7] Moleong, Lexy J. Metodologi Penelitian Kualitatif, PT Remaja Rosdakarya. Bandung, 2002

[8] Mulyadi, Activity-Based Cost System, UPP STIM YKPN Yogyakarta. Yogyakarta, 2007

[9] Mursyidi, Akuntansi Biaya Conventional Costing, Just In Time, Dan Activity-Based Costing, Refika Aditama, Bandung, 2010

[10] Tatang Sopian. 2006. Biodiesel Dari Tanaman Jarak, Artikel dalam Indonesia Energy Information Center, www.indeni.org diakses Desember 2010

[11] Syamsudin Manai, Membuat Sendiri Biodiesel, Penerbit Andi , Yogyakarta, 2010

[12] Agnes Fransisca Adie dan Riki Martusa. Peranan Activity-Based Costing System Dalam Perhitungan Harga Pokok Produksi Kain Yang Sebenarnya Untuk Penetapan Harga Jual, Akurat Jurnal Ilmiah

Radha Kurniawan : Penentuan Harga Jual Biji... 
\{ Halaman ini sengaja dikosongkan \} 